ENCYCLOPEEDIE Encyclopédie berbère

BERBERE

$7 \mid 1989$

7 | Asarakae - Aurès

\title{
Asile (droit d')
}

(voir Anaya A212)

\section{OpenEdition}

Journals

Édition électronique

URL : http://journals.openedition.org/encyclopedieberbere/2524

DOI : 10.4000/encyclopedieberbere.2524

ISSN : 2262-7197

Éditeur

Peeters Publishers

Édition imprimée

Date de publication : 1 janvier 1989

Pagination : 968

ISBN : 2-85744-443-5

ISSN : 1015-7344

\section{Référence électronique}

«Asile (droit d') », Encyclopédie berbère [En ligne], 7| 1989, document A293, mis en ligne le 19 mars

2012, consulté le 15 octobre 2020. URL : http://journals.openedition.org/encyclopedieberbere/2524

DOI : https://doi.org/10.4000/encyclopedieberbere.2524

Ce document a été généré automatiquement le 15 octobre 2020

(c) Tous droits réservés 


\section{Asile (droit d')}

(voir Anaya A212) 